\title{
Lunchtime food and nutrient intakes of secondary-school pupils; a comparison of school lunches and packed lunches following the introduction of mandatory food-based standards for school lunch
}

\author{
Jo Pearce, Lesley Wood and Michael Nelson* \\ Children's Food Trust, 3rd Floor, East Parade, Sheffield S1 2ET, UK
}

Submitted 24 October 2011: Final revision received 9 May 2012: Accepted 17 June 2012: First published online 24 August 2012

\begin{abstract}
Objective: To compare the key differences between school lunches and packed lunches as eaten in eleven secondary schools in England, 21 months after the food-based standards for school lunch became mandatory, but before the introduction of nutrient-based standards.

Design: Data on 358 school lunches and 139 packed lunches were collected in May and June 2008 from pupils attending secondary schools in Sheffield, Manchester, Leicester City and Essex. Fieldwork was conducted over five consecutive school days at each school. Fieldworkers randomly selected five pupils taking a school lunch and five pupils bringing a packed lunch each day. All food and drink items chosen by pupils were weighed and recorded. Leftovers were also weighed.

Setting: Eleven state-maintained, co-educational secondary schools from four local authorities in England.

Subjects: Four hundred and ninety-seven pupils aged 11-16 years.

Results: Pupils taking school lunches, on average, had significantly higher intakes of energy, protein, carbohydrate, NSP, vitamin C, folate, Fe and $\mathrm{Zn}$ than pupils bringing a packed lunch to school. Mean intakes of protein, fat and vitamin $\mathrm{C}$ from both types of lunch met the nutrient-based standards and school lunches also met standards for carbohydrate, NSP and energy.

Conclusions: Nutrient intakes from school lunches were more favourable than those from packed lunches, but typically failed to meet nutrient-based standards for school food. A combination of continued improvements to school food, educating pupils to make healthier choices and policies to encourage pupils to eat at school or bring healthier packed lunches is needed.
\end{abstract}

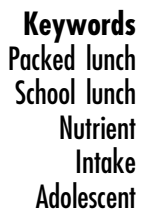

The nutritional quality of the food consumed by children at school is of international concern ${ }^{(1)}$. The food provided by schools, brought from home or purchased on the way to school is often energy dense and low in micronutrients and may be a contributing factor to the rise in childhood obesity ${ }^{(2)}$. The food provided in English primary schools is no exception, but has improved in recent years ${ }^{(3)}$, following a surge of interest from the media $^{(4)}$ and Government legislation aimed at improving school food $^{(5)}$. There is not, however, any similar legislation that covers what children can take to school as part of a packed lunch, although schools can choose to implement a packed lunch policy if they wish, for example, to limit confectionery or fizzy drinks brought from home ${ }^{(6)}$. In $2008,39 \cdot 3 \%$ of primary-school pupils and $35 \cdot 1 \%$ of secondary-school pupils ate a lunch provided by their school $^{(7)}$. The remainder brought a packed lunch from home, went home for lunch, ate food purchased outside school or had nothing for lunch.

Internationally, few studies compare school lunches with food brought from home or bought on the way to school. A relevant study on 10-12-year-olds in Canada showed the nutrient content of both meal types was poor, although when adjusted for energy content, school lunches were higher in $\mathrm{Ca}$ and vitamin $\mathrm{D}$ and lower in $\mathrm{Na}$ than packed lunches ${ }^{(8)}$. In the UK, recent studies 
comparing the nutrient intakes of primary-school pupils consuming a packed lunch with those taking a school lunch have shown that children who brought food from home chose less starchy foods, vegetables and salad and more dairy products, fruit, meat products, confectionery and savoury snacks, leading to higher intakes of total and saturated fat, carbohydrate, non-milk extrinsic sugars (NMES), vitamin $\mathrm{C}, \mathrm{Na}, \mathrm{Ca}$ and $\mathrm{Fe}$ but lower intakes of protein, NSP, vitamin A and Zn compared with those who bought a meal at school ${ }^{(9,10)}$. Only one study, also in the UK, has previously compared data from school lunches and packed lunches in 11-18-year-olds (data collected in 2006), and this showed few differences in nutrient content ${ }^{(11)}$.

A national survey of secondary-school meals carried out in $2004^{(12)}$, two years prior to the introduction of food-based standards, showed on average that pupils' intakes of total fat, saturated fat, NMES and $\mathrm{Na}$ were high (in relation to current guidelines ${ }^{(5)}$ ) while intakes of carbohydrate, NSP, vitamin A, vitamin C, folate, Ca and Fe were low. These results are consistent with intakes reported in the most recent National Diet and Nutrition Survey for 11-18-year-olds (assuming one-third of total daily intake occurs at lunchtime ${ }^{(13)}$ ) and a survey of school lunches in three secondary schools in Sheffield ${ }^{(14)}$.

Food provision at primary school is generally a twocourse lunch at a fixed price, markedly different from that in secondary schools where the food provision is almost exclusively in the form of cash cafeterias. Secondary pupils are allowed to spend at liberty and choose freely from the items of food and drink on offer, for example: a main meal and a dessert; a salad and bottle of fruit juice; two portions of potato wedges with cheese; or a pudding on its own. The greater freedom of choice offered by cash cafeterias in secondary schools reduces the impact of the school catering service in encouraging pupils to choose a healthy balanced meal. Instead, pupils are more directly responsible for making healthy choices from the range of food and drink items on offer.

The purpose of the food-based standards for school lunch, introduced in English secondary schools in September 2006, was to increase the number of portions of fruit and vegetables and healthier drinks (e.g. water, milk and fruit juice) available to pupils and to limit the frequency of sale of some items such as deep-fried foods (e.g. chips), meat products (e.g. sausages), confectionery (e.g. sweets and chocolate) and savoury snacks (e.g. crisps), but the number of portions of some of the less healthy items which may be high in salt, sugar and/or fat (such as high-fat main dishes, pizza, puddings and cakes) was not restricted. Although the standards aimed to balance provision in a way more likely to encourage healthier choices, evidence shows that many young people fail to choose a healthy, balanced meal when they are offered a free choice from a range of both healthy and less healthy food items ${ }^{(12)}$.
The data collection for the only study comparing school lunches with packed lunches in secondary schools ${ }^{(11)}$ was mainly carried out prior to the introduction of the foodbased standards. In addition the participants were mainly from high-income families. It therefore seemed appropriate to study this area further.

The objectives of the present paper were therefore to: (i) compare food choices and nutrient intakes from school lunches and packed lunches; and (ii) compare the nutrient density of packed lunches and school lunches as a measure of the quality of food consumed.

\section{Experimental methods}

Lunchtime dietary data were collected as part of a study looking at the effect of improving food provision and the dining room environment on pupil behaviour in the classroom after lunch ${ }^{(15)}$. In May 2008, all statecontrolled, co-educational secondary schools in four local authorities (Essex, Leicester City, Manchester and Sheffield) were invited to take part in a screening process for the study. Of a possible 113 schools, twenty-two (19.5\%) were screened on characteristics including: dining room characteristics, the catering provider, free school meal eligibility, Healthy Schools status and school lunch take-up. Twelve schools were selected to take part, although one school later dropped out. Data from this school were not included.

Fieldwork was conducted over the lunchtime period on five consecutive days at each school in May and June 2008. The lunchtime food consumption of at least five pupils taking a school lunch and five pupils eating a packed lunch was recorded each day by trained fieldworkers. Pupils were selected at random (for example, every fifth or tenth pupil, proportional to the number of pupils eating a school lunch at each school). Pupils were selected as they passed the till in the dining room (school lunches) or sat down to eat (packed lunches). Formal consent to participate was obtained from the senior leadership team in each school and individual pupils, when approached, were asked whether or not they wished to take part and were free to decline without having to give a reason. Four pupils who took a school lunch were excluded from the analysis as data on age or year group were missing. Fieldworkers were not able to sample five packed lunch pupils per day in every school, as some pupils ate their lunch outside the dining room or had started to eat their lunch before fieldworkers were able to approach them. On some occasions, more than the required five school lunches were sampled in some schools because there was time available. To calculate the portion weights served in school lunches, duplicate portions of twelve food items were chosen each day (sixty foods per school) and weighed by fieldworkers at the start of each lunch service. Average portion 
weights were then applied to school lunch choices made by pupils to determine the portion weight of food selected by each child. Food and drinks in packed lunches were weighed directly where possible. All leftovers from both school lunches and packed lunches were weighed and this weight was subtracted from starting portion weights to calculate the amount of each food actually eaten by each pupil. The weights of foods with missing portion weight data were estimated ${ }^{(16)}$. Recipes, cooking methods and product specification data were provided by the caterer at each school. Dietary data were coded by a nutritionist using the Food Standards Agency's nutrient databank to generate values for energy and nutrient intakes. Food groups were as classified on the databank.

Baseline data were analysed using the statistical software package SPSS for Windows version $15 \cdot 0$. Mean energy and nutrient intakes from school lunches and packed lunches were compared using analysis of covariance, adjusting for age, sex and school. The nutrient density of the two meal types was calculated by expressing the

Table 1 Number and percentage of pupils in the sample, by age and lunch type

\begin{tabular}{|c|c|c|c|c|c|c|}
\hline \multirow[b]{2}{*}{ Age (years) } & \multicolumn{2}{|c|}{ School lunch } & \multicolumn{2}{|c|}{ Packed lunch } & \multicolumn{2}{|c|}{ All } \\
\hline & $n$ & $\%$ & $n$ & $\%$ & $n$ & $\%$ \\
\hline 11 & 48 & $13 \cdot 4$ & 16 & $11 \cdot 5$ & 64 & $12 \cdot 9$ \\
\hline 12 & 99 & $27 \cdot 7$ & 60 & $43 \cdot 2$ & 159 & $32 \cdot 0$ \\
\hline 13 & 76 & $21 \cdot 2$ & 27 & $19 \cdot 4$ & 103 & $20 \cdot 7$ \\
\hline 14 & 73 & $20 \cdot 4$ & 16 & 11.5 & 89 & $17 \cdot 9$ \\
\hline 15 & 60 & $16 \cdot 8$ & 15 & $10 \cdot 8$ & 75 & $15 \cdot 1$ \\
\hline 16 & 2 & 0.6 & 5 & $3 \cdot 6$ & 7 & $1 \cdot 4$ \\
\hline Total & 358 & $100 \cdot 0$ & 139 & $100 \cdot 0$ & 497 & $100 \cdot 0$ \\
\hline
\end{tabular}

nutrient content as grams (milligrams or micrograms) per megajoule of energy.

The ethics committee of Kings College, London approved the study.

\section{Results}

Table 1 shows the ages of the pupils sampled; younger pupils were more likely to be sampled than older pupils, who were often allowed off site at lunchtime. Most Year 11 pupils (aged 15-16 years) had finished school to study for exams at the time of measurement.

Pupils who had a school lunch were more likely to have consumed vegetables (including vegetable dishes; $P=0 \cdot 004)$, fruit juice $(P<0 \cdot 001)$, baked beans $(P<0 \cdot 001)$, chips and other potatoes fried in oil $(P<0 \cdot 001)$, other potatoes $(P<0 \cdot 001)$ and puddings $(P<0 \cdot 001)$ compared with those eating a packed lunch. Pupils who brought a packed lunch ate salad and raw vegetables $(P=0 \cdot 008)$, fruit $(P<0.001)$, pasta, rice, pizza, bread and other cereals $(P<0 \cdot 001)$, meat and meat products $(P=0 \cdot 003)$, yoghurt, fromage frais and dairy desserts $(P<0 \cdot 001)$, soft drinks $(P<0 \cdot 001)$, cheese $(P=0 \cdot 015)$, crisps and other savoury snacks $(P<0 \cdot 001)$ and confectionery $(P<0 \cdot 001)$ more often than pupils who ate a school lunch (Table 2).

The average school lunch, as eaten, contained significantly more energy $(P=0 \cdot 030)$, protein $(P<0 \cdot 001)$, carbohydrate $(P=0.008)$, NSP $(P<0.001)$, vitamin $\mathrm{C}$ $(P=0 \cdot 009)$, folate $(P<0 \cdot 001)$, Fe $(P=0 \cdot 005)$ and $\mathrm{Zn}$ $(P<0 \cdot 001)$ than the average packed lunch, and a significantly lower percentage of energy from fat $(P=0 \cdot 035)$, saturated fat $(P=0 \cdot 014)$ and NMES $(P=0 \cdot 029$; Table 3$)$.

Table 2 Mean weight of food groups eaten (consumers only) and percentage of consumers, by lunch type: secondary-school pupils aged $11-16$ years ( $n$ 497), England, May and June 2008

\begin{tabular}{|c|c|c|c|c|c|c|c|}
\hline \multirow[b]{2}{*}{ Food group } & \multicolumn{3}{|c|}{ School lunch (n 358) } & \multicolumn{3}{|c|}{ Packed lunch (n 139) } & \multirow[b]{2}{*}{$P^{*}$} \\
\hline & Mean & SD & $\%$ consumers & Mean & SD & $\%$ consumers & \\
\hline Pasta, rice, pizza, bread, other cereals & $135 \cdot 4$ & $88 \cdot 2$ & 63 & $78 \cdot 5$ & $50 \cdot 4$ & 91 & $<0.001$ \\
\hline Biscuits, buns, cakes, pastries & $73 \cdot 6$ & $34 \cdot 2$ & 41 & $40 \cdot 5$ & $25 \cdot 0$ & 35 & $0 \cdot 221$ \\
\hline Puddings & $141 \cdot 7$ & $60 \cdot 5$ & 13 & $0 \cdot 0$ & $0 \cdot 0$ & 0 & $<0.001$ \\
\hline Cheese & $32 \cdot 3$ & $18 \cdot 6$ & 16 & $36 \cdot 6$ & $18 \cdot 8$ & 26 & 0.015 \\
\hline Yoghurt, fromage frais, dairy desserts & $103 \cdot 3$ & $67 \cdot 5$ & 1 & $78 \cdot 1$ & $33 \cdot 3$ & 14 & $<0.001$ \\
\hline White fish and dishes & $65 \cdot 6$ & $35 \cdot 0$ & 7 & $43 \cdot 3$ & $27 \cdot 5$ & 9 & 0.575 \\
\hline Oily fish and dishes & $0 \cdot 0$ & $0 \cdot 0$ & 0 & $55 \cdot 0$ & $42 \cdot 4$ & 1 & 0.077 \\
\hline Meat, meat dishes, meat products & $116 \cdot 5$ & $81 \cdot 1$ & 33 & $30 \cdot 5$ & $18 \cdot 3$ & 47 & 0.003 \\
\hline Salad and raw vegetables & $47 \cdot 7$ & $29 \cdot 0$ & 6 & $52 \cdot 1$ & $37 \cdot 9$ & 14 & 0.008 \\
\hline Vegetables and vegetable dishes & $123 \cdot 1$ & $90 \cdot 3$ & 11 & $9 \cdot 8$ & $4 \cdot 6$ & 3 & 0.004 \\
\hline Baked beans & $117 \cdot 4$ & $22 \cdot 1$ & 26 & $66 \cdot 0$ & $66 \cdot 0$ & 1 & $<0.001$ \\
\hline Chips, fried/roast potatoes, potato products & $179 \cdot 2$ & $53 \cdot 3$ & 25 & $0 \cdot 0$ & $0 \cdot 0$ & 0 & $<0.001$ \\
\hline Other potatoes, potato salads & $143 \cdot 4$ & $73 \cdot 0$ & 17 & $117 \cdot 5$ & $4 \cdot 9$ & 1 & $<0.001$ \\
\hline Crisps, savoury snacks, nuts & $25 \cdot 0$ & $25 \cdot 0$ & 1 & $25 \cdot 1$ & $5 \cdot 7$ & 38 & $<0.001$ \\
\hline Fruit & $145 \cdot 4$ & $45 \cdot 3$ & 4 & $95 \cdot 5$ & $64 \cdot 9$ & 31 & $<0.001$ \\
\hline Fruit juice & $248 \cdot 0$ & $109 \cdot 3$ & 23 & $218 \cdot 3$ & $101 \cdot 3$ & 6 & $<0.001$ \\
\hline Water & 375.9 & $154 \cdot 2$ & 8 & $309 \cdot 7$ & $218 \cdot 6$ & 16 & 0.013 \\
\hline Soft drinks & $288 \cdot 2$ & $126 \cdot 1$ & 18 & $274 \cdot 5$ & $127 \cdot 6$ & 40 & $<0.001$ \\
\hline Confectionery & $20 \cdot 0$ & $0 \cdot 0$ & 1 & $35 \cdot 2$ & $24 \cdot 1$ & 19 & $<0.001$ \\
\hline
\end{tabular}

${ }^{*} \chi^{2}$ test of association between type of food and type of lunch. 
Table 3 Average energy and nutrient intakes at lunchtime, by type of lunch: secondary-school pupils aged 11-16 years ( $n$ 497), England, May and June 2008

\begin{tabular}{|c|c|c|c|c|c|c|c|}
\hline \multirow[b]{2}{*}{ Nutrient } & \multirow[b]{2}{*}{ Nutrient-based standard } & \multicolumn{2}{|c|}{ School lunch ( $n$ 358) } & \multicolumn{2}{|c|}{ Packed lunch (n 139) } & \multirow[b]{2}{*}{ Difference* } & \multirow[b]{2}{*}{$P+$} \\
\hline & & Mean & SD & Mean & SD & & \\
\hline Energy $(\mathrm{kJ})$ & $2705 \pm 135$ & $2734 \cdot 4$ & $1123 \cdot 4$ & $2292 \cdot 3$ & $1059 \cdot 8$ & $442 \cdot 1$ & 0.030 \\
\hline Protein $(\mathrm{g})$ & $\geq 13.3$ & $22 \cdot 4$ & 11.5 & $15 \cdot 5$ & $7 \cdot 6$ & $6 \cdot 9$ & $<0.001$ \\
\hline Carbohydrate (g) & $\geq 86 \cdot 1$ & $89 \cdot 2$ & 38.9 & $72 \cdot 2$ & $34 \cdot 4$ & $17 \cdot 0$ & 0.008 \\
\hline NMES (g) & $\leq 18 \cdot 9$ & $22 \cdot 0$ & $18 \cdot 4$ & $20 \cdot 4$ & $20 \cdot 6$ & $1 \cdot 6$ & $0 \cdot 84 C$ \\
\hline Fat $(\mathrm{g})$ & $\leq 25 \cdot 1$ & $25 \cdot 1$ & $14 \cdot 2$ & 6 & $14 \cdot 3$ & 1.5 & 0.570 \\
\hline Saturated fat (g) & $\leq 7 \cdot 9$ & $9 \cdot 0$ & $6 \cdot 0$ & $9 \cdot 7$ & $6 \cdot 7$ & $-0 \cdot 7$ & 0.616 \\
\hline $\mathrm{NSP}(\mathrm{g})$ & $\geq 5 \cdot 2$ & $5 \cdot 5$ & $3 \cdot 0$ & $2 \cdot 9$ & $1 \cdot 7$ & $2 \cdot 6$ & $<0.001$ \\
\hline $\mathrm{Na}(\mathrm{mg})$ & $\leq 714 \cdot 0$ & $737 \cdot 9$ & $417 \cdot 3$ & $748 \cdot 4$ & $383 \cdot 0$ & $-10 \cdot 5$ & 0.975 \\
\hline Vitamin A $(\mu \mathrm{g})$ & $\geq 245 \cdot 0$ & $200 \cdot 9$ & $222 \cdot 5$ & $195 \cdot 7$ & 335.9 & $5 \cdot 2$ & 0.521 \\
\hline Vitamin C (mg) & $\geq 14 \cdot 0$ & $32 \cdot 3$ & $37 \cdot 6$ & $21 \cdot 3$ & $29 \cdot 5$ & $11 \cdot 0$ & 0.009 \\
\hline Folate $(\mu \mathrm{g})$ & $\geq 70 \cdot 0$ & $66 \cdot 6$ & $36 \cdot 9$ & $38 \cdot 6$ & $19 \cdot 8$ & $28 \cdot 0$ & $<0.001$ \\
\hline $\mathrm{Ca}(\mathrm{mg})$ & $\geq 350 \cdot 0$ & $273 \cdot 5$ & $190 \cdot 8$ & $242 \cdot 6$ & $147 \cdot 3$ & $30 \cdot 9$ & $0 \cdot 215$ \\
\hline $\mathrm{Fe}(\mathrm{mg})$ & $\geq 5 \cdot 2$ & $3 \cdot 3$ & $1 \cdot 6$ & $2 \cdot 2$ & $1 \cdot 2$ & $1 \cdot 1$ & 0.005 \\
\hline Zn (mg) & $\geq 3 \cdot 3$ & $2 \cdot 5$ & $1 \cdot 3$ & $1 \cdot 6$ & 0.9 & 0.9 & $<0.001$ \\
\hline \multicolumn{8}{|c|}{ Percentage of energy from } \\
\hline Protein & - & $3 \cdot 5$ & $1 \cdot 4$ & $3 \cdot 0$ & $1 \cdot 2$ & 0.5 & $<0.001$ \\
\hline Fat & $\leq 35$ & $33 \cdot 4$ & $11 \cdot 7$ & $37 \cdot 0$ & $11 \cdot 4$ & $-3 \cdot 6$ & 0.035 \\
\hline Saturated fat & $\leq 11$ & $12 \cdot 0$ & $6 \cdot 0$ & $15 \cdot 1$ & $6 \cdot 7$ & $-3 \cdot 1$ & 0.014 \\
\hline Carbohydrate & $\geq 50$ & $52 \cdot 5$ & $12 \cdot 0$ & $51 \cdot 2$ & $12 \cdot 4$ & $0 \cdot 3$ & 0.499 \\
\hline NMES & $\leq 11$ & $12 \cdot 6$ & $10 \cdot 1$ & $14 \cdot 5$ & $15 \cdot 7$ & -1.9 & 0.029 \\
\hline
\end{tabular}

NMES, non-milk extrinsic sugars.

*School lunch - packed lunch.

tAnalysis of covariance comparing mean intakes of energy, adjusted for age, sex and school.

Table 4 Average energy intake (MJ) and nutrient density ( $\mathrm{g}, \mathrm{mg}$ or $\mu \mathrm{g}$ per $\mathrm{MJ}$ ) of lunch as eaten, by type of lunch: secondary-school pupils aged 11-16 years ( $n$ 497), England, May and June 2008

\begin{tabular}{|c|c|c|c|c|c|c|}
\hline \multirow[b]{2}{*}{ Nutrient } & \multicolumn{2}{|c|}{ School lunch ( $n$ 358) } & \multicolumn{2}{|c|}{ Packed lunch (n 139) } & \multirow[b]{2}{*}{ Difference* } & \multirow[b]{2}{*}{$P+$} \\
\hline & Mean & SD & Mean & SD & & \\
\hline Energy (MJ) & $2 \cdot 7$ & $1 \cdot 1$ & $2 \cdot 3$ & $1 \cdot 1$ & 0.4 & $<0.001$ \\
\hline Protein (g/MJ) & $8 \cdot 4$ & $3 \cdot 3$ & $7 \cdot 1$ & $2 \cdot 8$ & $1 \cdot 3$ & 0.529 \\
\hline Carbohydrate (g/MJ) & $33 \cdot 1$ & $7 \cdot 4$ & $32 \cdot 4$ & $7 \cdot 7$ & $0 \cdot 7$ & 0.026 \\
\hline NMES (g/MJ) & $8 \cdot 0$ & $6 \cdot 4$ & $9 \cdot 2$ & $9 \cdot 9$ & $-1 \cdot 2$ & 0.034 \\
\hline Fat $(\mathrm{g} / \mathrm{MJ})$ & $8 \cdot 8$ & $3 \cdot 1$ & $9 \cdot 8$ & $3 \cdot 0$ & $-1 \cdot 0$ & 0.014 \\
\hline Saturated fat $(\mathrm{g} / \mathrm{MJ})$ & $3 \cdot 2$ & $1 \cdot 6$ & $4 \cdot 0$ & $1 \cdot 8$ & -0.8 & $<0.001$ \\
\hline NSP (g/MJ) & $2 \cdot 1$ & $1 \cdot 1$ & $1 \cdot 3$ & 0.8 & 0.8 & 0.070 \\
\hline $\mathrm{Na}(\mathrm{mg} / \mathrm{MJ})$ & $277 \cdot 1$ & $142 \cdot 6$ & $327 \cdot 2$ & $116 \cdot 0$ & $-50 \cdot 1$ & 0.974 \\
\hline Vitamin A ( $\mu \mathrm{g} / \mathrm{MJ})$ & $78 \cdot 9$ & $105 \cdot 4$ & $88 \cdot 8$ & $207 \cdot 7$ & $-10 \cdot 1$ & 0.626 \\
\hline Vitamin C (mg/MJ) & $14 \cdot 1$ & $20 \cdot 1$ & $12 \cdot 3$ & $20 \cdot 8$ & $1 \cdot 8$ & 0.002 \\
\hline Folate $(\mu \mathrm{g} / \mathrm{MJ})$ & $26 \cdot 1$ & $14 \cdot 4$ & $18 \cdot 5$ & $11 \cdot 4$ & $7 \cdot 6$ & 0.604 \\
\hline $\mathrm{Ca}(\mathrm{mg} / \mathrm{MJ})$ & $101 \cdot 3$ & $61 \cdot 1$ & $109 \cdot 0$ & $55 \cdot 2$ & $-7 \cdot 7$ & 0.007 \\
\hline $\mathrm{Fe}(\mathrm{mg} / \mathrm{MJ})$ & $1 \cdot 2$ & $0 \cdot 4$ & $1 \cdot 0$ & 0.5 & 0.2 & $<0.001$ \\
\hline $\mathrm{Zn}(\mathrm{mg} / \mathrm{MJ})$ & $1 \cdot 0$ & $0 \cdot 4$ & $0 \cdot 7$ & $0 \cdot 3$ & 0.3 & $<0.001$ \\
\hline
\end{tabular}

NMES, non-milk extrinsic sugars.

*School lunch - packed lunch.

tAnalysis of covariance comparing mean intakes of energy and nutrients (per MJ of energy consumed) adjusted for age, sex and school.

Mean intakes from both school lunches and packed lunches met the nutrient-based standards ${ }^{(5)}$ for protein, fat and vitamin C. In addition, intake from school lunches also met the nutrient-based standards for energy, carbohydrate and NSP.

Intake from school lunches provided over threequarters of the recommended lunchtime amount of Zn (76\%), Ca (78\%), vitamin A (82\%) and folate (95\%), but less than two-thirds of the recommended lunchtime amount for $\mathrm{Fe}(63 \%)$. In contrast, intake from packed lunches provided approximately half the recommended lunchtime amount of $\mathrm{Fe}$ (42\%), Zn (48\%), folate $(55 \%)$ and NSP (56\%), while providing nearly a quarter more saturated fat $(23 \%)$ than recommended by the standards.

In comparison with the average packed lunch, the average school lunch had a higher density of vitamin $\mathrm{C}$ $(P=0.002)$, Fe $(P<0.001)$ and $\mathrm{Zn}(P<0.001)$ and a lower density of NMES $(P=0.034)$, fat $(P=0.014)$ and saturated fat $(P<0 \cdot 001)$ per megajoule (Table 4$)$. The average packed lunch was denser in $\mathrm{Ca}(P=0 \cdot 007)$, although the difference was small $(8 \mathrm{~g} / \mathrm{MJ})$. 


\section{Discussion}

The percentage of children eating foods from each food group differed between the school lunch and packed lunch groups and was consistent with previous studies in primary schools ${ }^{(10,17,18)}$. As expected, foods traditionally served hot (vegetables, baked beans, potatoes and puddings) were eaten more frequently by those who ate a school lunch while cold and finger foods were consumed by a higher proportion of pupils eating a packed lunch. The resulting intakes of energy and micronutrients were more favourable (closer to the school lunch standards) among those pupils eating a school lunch. There were no significant differences between the two groups in absolute intakes of fat, saturated fat, NMES or Na, around which public health messages are currently focused ${ }^{(19,20)}$. This contrasts with results from studies in primary schools where intakes of these nutrients were lower among pupils eating a school meal ${ }^{(9,14,17)}$. When adjusted for energy (percentage of energy from fat, saturated fat and NMES, or $\mathrm{g} / \mathrm{MJ}$ ), however, the macronutrient profile of food consumed as part of a school lunch was more favourable than that from packed lunches, although only percentage of energy from fat in school lunches was within the recommended limit. Percentage of energy from carbohydrate met the standards for both types of meal.

Confectionery and savoury snack consumption were low among pupils eating a school lunch in this sample, which is unsurprising as these foods are no longer permitted under the food-based standards for school food. A high proportion of children choosing school lunch did, however, consume fried/roast potatoes (25\%), cakes and biscuits (41\%) and soft drinks (18\%, although not allowed under the standards), while few ate vegetables (11\%), salad (6\%) and fruit (5\%). The frequency of consumption of all fruit and vegetables among children eating a school lunch was higher than in $2004^{(12)}$, but schools often rely on fruit juice and baked beans as the provided fruit and vegetable options, with pupils twice as likely to choose baked beans than other vegetables/vegetable dishes and five times more likely to choose fruit juice than fresh, canned or dried fruit.

Pupils eating a packed lunch ate less food (by weight) than those who chose a school lunch $(367 \mathrm{~g}$ and $480 \mathrm{~g}$, respectively), associated with lower energy intakes at lunchtime. It may be, however, that packed lunch pupils consumed some of the contents of their lunch boxes at mid-morning break, which was not monitored as part of the present study ${ }^{(15)}$. Similarly, intakes at breakfast and mid-morning break may also impact on the lunchtime food choices of children eating either type of lunch, but again these were beyond the scope of the present study.

The study was unable to determine any differences which may be attributable to seasonality, packed lunch policies enforced in some schools, socio-economic status and attitudes to food (particularly school food). These could be included in future research.

Food-based standards may have improved the nutrient profile of the average school meal (as consumed in this sample) compared with national data published in $2004^{(12)}$, but may not be enough to ensure that pupils who are eating a school lunch meet current Government recommendations ${ }^{(5)}$. Nutrient-based standards introduced in September 2009 aimed to improve further the nutrient density of the food provided in secondary schools, and to further restrict the number and portion sizes of energy-dense, micronutrient-poor foods that were available to pupils (e.g. fried potatoes and cakes and biscuits) that could be provided relatively freely while there were food-based standards alone. It is hoped that the restriction on popular high-fat and high-sugar items will result in further dietary improvements. The present findings suggest that improvements in school lunch provision, following the introduction of the standards, has not spread to packed lunch provision and the nutrient profile of packed lunches may have worsened in recent years ${ }^{(18)}$.

In addition to meeting standards, food also needs to be attractive to secondary-school pupils who, as customers, make their own food choices and create a meal from the food on offer, unlike pupils at primary school. Older children may decide to bring a packed lunch if they perceive that school food is expensive, unappealing, or they do not feel they have a choice of food options as they would with a packed lunch ${ }^{(21)}$.

In 2008, over half of secondary-school pupils brought a packed lunch to school $^{(7)}$, and this is still the case ${ }^{(22)}$. Alongside the introduction of standards for school food, and working to ensure that school meals are an appealing option for pupils, schools should endeavour to improve the lunchtime nutrient intake of all pupils, including those who choose to bring food from home or purchase food outside the school at lunchtime. The most direct way of doing this is to encourage more pupils to have a school meal and, critically, to improve the quality of the dining environment at school, as issues such as queuing have a major impact on pupils' decision to take a school lunch or not. Implementing a stay-on-site policy (to prevent pupils from leaving the school at lunchtime to purchase food from fast-food outlets) clearly also has a direct impact on take-up. Introducing a packed lunch policy which restricts foods high in fat, sugar and salt being brought to school is in theory useful, but difficult to enforce in practice. Ultimately, educating pupils to make healthier lunchtime choices from the food available must be supported by appropriate actions in the dining room that make healthy eating the default option. The divergence between school lunches and packed lunches is likely to grow as more pupils take the healthier options in school, while improvements in packed lunches lag behind. 


\section{Acknowledgements}

This research was funded by the School Food Trust. The authors declare no conflict of interest. J.P. designed the study, trained fieldworkers, coded and analysed the data and wrote the paper. M.N. contributed to study design and writing the paper. L.W. advised on data analysis and writing the paper. The authors would like to thank all of the schools, pupils and caterers who took part in the study, as well as the National Centre for Social Research (NatCen) for carrying out the fieldwork.

\section{References}

1. Harper C \& Wells L (2007) School meal provision in England and other western countries: a review. http:// www.schoolfoodtrust.org.uk/school-cooks-caterers/reports/ school-meal-provision-in-england-and-other-western-countriesa-review (accessed May 2012).

2. Wang $\mathrm{Y} \&$ \& Lobstein $\mathrm{T}$ (2003) Worldwide trends in childhood overweight and obesity. Int J Pediatr Obes 1, $11-25$.

3. Haroun D, Harper C, Wood L et al. (2011) The impact of the food-based and nutrient-based standards on lunchtime food and drink provision and consumption in primary school in England. Public Health Nutr 14, 209-218.

4. Channel 4 (2005) 'Jamie's school dinners' television program. http://www.channel4.com/life/microsites/J/jamies_ school_dinners/index.html (accessed February 2011).

5. Department for Education and Skills (2007/2008) The Education (Nutritional Standards and Requirements for School Food) (England) Regulations 2007 (SI 2007/2359) as amended by the Education (Nutritional Standards and Requirements for School Food) (England) (Amendment) Regulations 2008 (SI 2008/1800). London: TSO; available at http://www.opsi.gov.uk/si/si2007/uksi_20072359_en_1, http://www.opsi.gov.uk/si/si2008/uksi_20081800_en_1

6. The School Food Trust (year?) Example packed lunch policy. http://www.schoolfoodtrust.org.uk/schools/projects/ packed-lunches/example-packed-lunch-policy (accessed February 2011).

7. Nelson M, Nicholas J, Wood L et al. (2009) Statistical Release: National Indicator 52; Take up of school lunches in England 2008-9. http://www.schoolfoodtrust.org.uk/ school-cooks-caterers/reports/statistical-release-ni-52-take-upof-school-lunches-in-england-2008-2009 (accessed February 2011)

8. Taylor JP, Hernandez KJ, Caiger JM et al. (2012) Nutritional quality of children's school lunches: differences according to food source. Public Health Nutr (Epublication ahead of print version).
9. Rees GA, Richards CJ \& Gregory J (2008) Food and nutrient intakes of primary school children: a comparison of school meals and packed lunches. J Hum Nutr Diet 21, 420-427.

10. Pearce J, Harper C, Wood L et al. (2011) Key differences between school lunches and packed lunches in primary schools in England in 2009. Public Health Nutr 14, 1507-1510.

11. Prynne CJ, Handford C, Dunn V et al. (2011) The quality of midday meals eaten at school by adolescents; school lunches compared with packed lunches and their contribution to total energy and nutrient intakes. Public Health Nutr (Epublication ahead of print version).

12. Nelson M, Bradbury J, Poulter J et al. (2004) Department for Education and Skills and Food Standards Agency. School meals in secondary schools in England. http://www. dcsf.gov.uk/research/data/uploadfiles/RR557.pdf (accessed February 2011).

13. Food Standards Agency \& Department of Health (2010) National Diet and Nutrition Survey: Headline results from Year 1 of the Rolling Programme (2008/2009). http:// tna.europarchive.org/20110116113217/http://www.food.gov. uk/science/dietarysurveys/ndnsdocuments/ndns0809year1 (accessed February 2011)

14. Gould R, Russell J \& Marker M (2006) School lunch menus and 11-12 year old children's food choice in three secondary schools in England - are the nutritional standards being met? Appetite 46, 86-92.

15. Storey CH, Pearce J, Ashfield-Watt PAL et al. (2010) A randomised controlled trial of the effect of school food and dining room modifications on classroom behaviour in secondary school children. Eur J Clin Nutr 65, 32-38.

16. Food Standards Agency (2002) Food Portion Sizes, 3rd ed. London: The Stationery Office.

17. Rogers IS, Ness AR, Hebditch K et al. (2007) Quality of food eaten in English primary schools: school dinners versus packed lunches. Eur J Clin Nutr 61, 856-864.

18. Evans CEL, Cleghorn CL, Greenwood DC et al. (2010) A comparison of British school meals and packed lunches from 1990 to 2007: meta-analysis by lunch group. Br J Nutr 104, 474-487.

19. NHS Choices (2011) The Eatwell Plate. http://www.nhs. uk/Livewell/Goodfood/Pages/eatwell-plate.aspx (accessed June 2011).

20. Change4Life Campaign (2011) ChangefLife. http://www. nhs.uk/change4life/pages/change-for-life.aspx (accessed June 2011).

21. School Food Trust (2007) Young Peoples' Opinions of School Meals: A Telephone Survey. Sheffield: School Food Trust; available at http://www.schoolfoodtrust.org.uk/ schools/reports/young-peoples-opinions-of-school-mealsa-telephone-survey.

22. Nelson M, Nicholas J, Wood L et al. (2011) Statistical Release: Take up of school lunches in England 2011-2012. http://www.schoolfoodtrust.org.uk/school-cooks-caterers/ reports/statistical-release-take-up-of-school-lunches-inengland-2011-2012 (accessed July 2012). 